\title{
PSIKOLOGI PERKEMBANGAN MANUSIA DALAM PENDIDIKAN ISLAM
}

\author{
Mappanyompa $^{1}$, Hidayatussaliki² \\ ${ }^{1}$ Program Studi KPI, ${ }^{2}$ Program Studi PGMI, Universitas Muhammadiyah Mataram, Indonesia \\ Mayompakaltim@gmail.com ${ }^{1}$, hidayatussaliki1987@gmail.com ${ }^{2}$
}

\begin{tabular}{l}
\hline INFO ARTIKEL \\
\hline Riwayat Artikel: \\
Diterima: $02-07-2021$ \\
Disetujui: $31-10-2021$ \\
\end{tabular}

\section{Kata Kunci:}

Psikologi perkembangan, Perkembangan manusia, Pendidikan Islam;

Keywords:

Developmental psychology,

Human development,

Islamic education;

\begin{abstract}
ABSTRAK
Abstrak:
Manusia merupakan makhluk yang berkembang, dan dalam perkembangannya lebih sempurna dibandingkan dengan makhluk yang lain. Manusia adalah makhluk ciptaan Allah SWT yang paling mulia di antara makhluk ciptaan lainnya. Hal ini disebabkan karena manusia dilengkapi dengan semua pembawaan dan syarat-syarat yang diperlukan. Menurut Al-Qur'an, manusia pada tabiatnya adalah homo religious (makhluk beragama) yang sejak lahirnya telah membawa suatu kecenderungan beragama. Pendidikan Islam masa pranatal disebut juga dalam bahasa arab tarbiyah qabl al-wiladah, pendidikan pranatal adalah pendidikan sebelum masa melahirkan yang ditandai dengan fase pemilihan jodoh, pernikahan, dan kehamilan. kemudian berlanjut kepada fase pendidikan Islam masa pascanatal atau tarbiyah ba'da al-wiladah, pendidikan pascanatal yaitu pendidikan yang dimulai sejak lahirnya anak sampai mereka dewasa, bahkan sampai meninggal dunia yang kita kenal dengan sebutan pendidikan seumur hidup. Didalam rahim setiap janin terlindung dari semua pengaruh kondisi luar kecuali yang dapat sampai melalui ibu yang mengandungnya. Rasa aman dan perlindungan itu tidak akan pernah ditemui anak setelah ia lahir. Pendidikan pascanatal memiliki beberapa fase diantaranya: 1) Fase bayi, ialah fase kehidupan manusia terhitung dari saat kelahiran sampai kira-kira berumur dua tahun. Selama rentang waktu itu, kehidupan bayi biasanya sangat tergantung pada bantuan dan pemeliharaan pihak lain, terutama si ibu. Peranan ibu yang demikian besarnya terhadap si bayi itu tentu mempunyai arti tersendiri bagi pendidikannya. 2) fase kanan-kanak. 3) fase anak-anak. 4) fase remaja. 5) fase dewasa.
\end{abstract}

\begin{abstract}
:
Humans are creatures that develop, and in their development are more perfect than other creatures. Humans are the noblest creatures created by Allah SWT among other creatures. This is because humans are equipped with all the necessary traits and conditions. According to the Qur'an, humans are homo religious by nature (religious beings) who from birth have brought a religious tendency. Prenatal Islamic education is also called in Arabic tarbiyah qabl al-wiladah, prenatal education is education before childbirth which is marked by the phase of choosing a mate, marriage, and pregnancy. then continues to the postnatal phase of Islamic education or tarbiyah ba'da al-wiladah, postnatal education, namely education that starts from the birth of children until they are adults, even until death which we know as lifelong education. In the womb of every fetus is protected from all influences from outside conditions except those that can reach through the mother who carries it. This sense of security and protection will never be met by a child after he is born. Postnatal education has several phases including: 1) Infancy phase, is the phase of human life starting from the time of birth until approximately two years old. During that time, the baby's life is usually very dependent on the help and care of others, especially the mother. The role of such a large mother to the baby certainly has its meaning for education. 2) right-child phase. 3) childhood phase. 4) adolescent phase. 5) adult phase.
\end{abstract}

\section{A. LATAR BELAKANG}

Perkembangan manusia di mulai pada saat konsepsi atau pembuahan, yaitu pada pembuahan telur oleh spermatosoma. Bila spermatosoma lakilaki (sperma) memasuki dinding telur (ovum) wanita terjadi konsepsi dan terbentuknya zigot.
Karena itu, masa ini bukan saja merupakan periode khusus dalam rentang kehidupan manusia tetapi juga merupakan periode yang sangat menentukan. Secara biologis hidup itu di mulai pada waktu konsepsi atau pembuahan. Masa ini pada umumnya berlangsung selama 9 bulan atau sekitar 280 hari sebelum lahir. Dilihat dari waktunya, 
periode ini (prenatal) merupakan periode perkembangan manusia yang sangat singkat, tetapi justru pada periode inilah di pandang terjadi perkembangan yang sangat cepat dalam diri manusia. Pada masa-masa awal ini penelitianpenelitian yang dilakukan oleh sebagian besar ahli psikologi barat cenderung di mulai dari periode bayi yang baru lahir dan mengabaikan periode prenatal. Kemudian pada muncul kesadaran bahwa mengetahui segala kejadian pada masa prenatal sangat penting untuk dapat memahami secara utuh pola perkembangan yang normal.

Perkembangan merupakan pola pergerakan atau perubahan yang terjadi sepanjang rentang kehidupan. Perkembangan di pengaruhi oleh hubungan antara proses biologis, kognitif dan sosial-emosi. Perkembangan secara umum dibagi menjadi periode yang dimulai dari pertumbuhan hingga masa remaja, perkelahiran, masa bayi, masa kanak-kanak awal, masa kanak-kanak tengah dan akhir, dan masa remaja. Beberapa ahli perkembangan menggambarkan perkembangan sebagai berkesinambungan (perubahan yang bertahap dan kumulatif), sementara yang lain menggambarkan sebagai tidak berkesinambungan (serangkaian tahapan tiba-tiba).

Manusia merupakan makhluk yang berkembang, dan dalam perkembangannya lebih sempurna dibandingkan dengan makhluk yang lain. Manusia adalah makhluk ciptaan Allah SWT yang paling mulia di antara makhluk ciptaan lainnya. Hal ini disebabkan karena manusia dilengkapi dengan semua pembawaan dan syaratsyarat yang diperlukan. Menurut Al-Qur'an, manusia pada tabiatnya adalah homo religious (makhluk beragama) yang sejak lahirnya telah membawa suatu kecenderungan beragama. Dalam hal ini, pada Allah berfirman:

"Maka hadapkanlah wajahmu dengan lurus kepada agama (Allah); (tetaplah di atas) fitrah Allah yang telah menciptakan manusia menurut fitrah itu. Tidak ada perubahan pada fitrah Allah. (Itulah) agama yang lurus, tetapi kebanyakan manusia tidak mengetahui". (QS. al-Rum [30]: 30.

Ayat di atas, mengandung interpretasi bahwa manusia diciptakan oleh Allah mempunyai naluri beragama, yaitu agama tauhid. Potensi fitrah Allah pada diri manusia ini menyebabkannya selalu mencari realitas mutlak, dengan cara mengekspresikannya dalam bentuk sikap, cara berpikir dan bertingkah laku. Karena sikap ini manusia disebut juga sebagai homo educandum (makhluk yang dapat didik) dan homo education (makhluk pendidik), karena pendidikan baginya adalah suatu keharusan guna mewujudkan kualitas dan integritas kepribadian yang utuh.
Posisi manusia sebagai homo religious dan homo educandum serta homo education sebagaimana disebutkan di atas, mengindikasikan bahwa sikap kegiatan belajar bagi setiap manusia dapat diarahkan melalui proses pendidikan dengan memandang fitrah sebagai obyek yang harus dikembangkan dan disempurnakan, dengan cara membimbing dan mengasuhnya agar dapat memahami, menghayati dan mengamalkan ajaranajaran keagamaan (Islam) secara universal. Betapapun juga, faktor keturunan tidaklah merupakan suatu yang kaku hingga tidak bisa dipengaruhi. Bahkan ia bisa dilenturkan dalam batas tertentu. Alat untuk melentur dan mengubahnya ialah lingkungan dengan segala usahanya. Lingkungan sekitar ialah aspek pendidikan yang penting. Ditegaskan pula dalam sebuah hadis, yaitu:

Dari Abi Hurairah ra, bahwa Nabi saw. bersabda: "setiap anak yang lahir, dilahirkan dalam keadaan fitrah, maka orang tualah yang menjadikan ia Yahudi, Nasrani atau Majusi". (HR. Muslim)

Kata fitrah (pembawaan) dalam hadis di atas, dan sebagaimana pula yang telah dijelaskan bahwa, ia mengandung arti potensi dasar yang dibawa oleh setiap manusia sejak lahir. Potensi ini adalah kepribadian Islam, namun potensi kepribadian tersebut kadangkala tidak bisa berkembang karena keadaan lingkungan yang tidak mendukung. Seorang anak memungkinkan saja berkepribadian Yahudi atau Nasrani bila tidak ada usaha orangtua (lingkungan) yang mengarahkannya. Dapat dirumuskan bahwa Islam mengakui faktor keturunan (bakat, pembawaan) dan faktor lingkungan (pengalaman) sebagai penentu baik dan buruknya kepribadian. Akan tetapi di samping kedua faktor tersebut masih ada lagi faktor lain yang cukup berpengaruh, yaitu hidayah Allah swt. Bahkan faktor hidayah ini sering lebih dominan dalam menentukan sosok kepribadian. Seorang anak, yang sudah terbiasa berakhlak buruk sejak kecil, tidak menunaikan kewajiban agama, namun pada suatu saat, setelah ia mendapat hidayah Allah SWT, ia menjadi anak shaleh dan sangat tampak dalam perilakunya.

Istilah perkembangan berarti serangkaian perubahan progresif yang terjadi sebagai akibat dari proses kematangan dan pengalaman. Seperti yang dikatakan oleh Van Den Daele "perkembangan berarti perubahan secara kualitatif". Ini berarti bahwa perkembangan bukan sekedar penambahan beberapa sentimeter pada tinggi badan seseorang atau peningkatan kemampuan seseorang, melainkan suatu proses 
integrasi dari banyak struktur dan fungsi yang kompleks.

Pada dasarnya ada dua proses perkembangan yang saling bertentangan yang terjadi secara serempak selama kehidupan, yaitu pertumbuhan atau evolusi dan kemunduran atau involusi. Keduanya mulai dari pembuahan dan berakhir dengan kematian.

\section{Perubahan dan Perkembangan}

Perkembangan berarti terjadi proses kesinambungan, dan proses itu bersifat siklikal. Dalam arti, Perkembangan itu memunculkan tanda-tanda akan berkembangnya kemampuankemampuan dan kemudian menghilang dan kemampuan yang hilang itu akan muncul kembali pada usia berikutnya. Perubahan yang terjadi dalam proses perkembangan manusia itu bertujuan untuk memungkinkan seseorang menyesuaikan diri dengan lingkungannya. Untuk mencapai tujuan itu, tindakan aktualisasi diri adalah sangat penting.

Banyak orang yang tidak menyadari tejadinya perubahan fisik dan psikis kecuali apabila perubahan itu berlangsung cepat dan mempengaruhi kehidupannya. Perubahan yang terjadi pada masa remaja, misalnya, akan berlangsung lebih cepat dibandingkan dengan masa usia lanjut, dan setiap individu dituntut mampu menyesuaikan diri dengan setiap perubahan yang terjadi pada dirinya. Oleh karena itu, apabila seseorang menyadari akan adanya perubahan pada dirinya, maka dia akan mengambil sikap yang jelas terhadap perubahan tersebut.

\section{Pertunbuhan dan Perkembangan}

Pertumbuhan berkaitan dengan perubahan kuantitatif, yaitu peningkatan ukuran dan struktur. Tidak saja anak itu menjadi lebih besar secara fisik, tetapi ukuran organ dalam dan otak meningkat. Akibat adanya pertumbuhan otak, anak memunyai kemampuan yang lebih besar dalam belajar, mengingat dan berpikir. Tidak dibedakannya antara istilah pertumbuhan dan perkembangan, bahkan ada psikolog tumbuhan yang lebih setuju dengan istilah pertumbuhan, adalah untuk menunjukan bahwa seseorang bertambah dalam kemampuannya, bahwa ia lebih mengalami deferensiasi dan juga ia pada tingkatan yang lebih tinggi, lebih mengalami integrasi. Istilah pertumbuhan dimaksudkan bagi pertumbuhan dalam ukuran-ukuran badan dan fungsi-fungsi fisik. Kemudian istilah perkembangan dimaksudkan sebagai perubahan yang mencerminkan sifat-sifat yang khas mengenai gejala-gejala psikologis yang tampak.

\section{B. PERKEMBANGAN PRANATAL DALAM PENDIDIKAN ISLAM (TARBIYAH QABL AL-WILADAH)}

Pendidikan Islam diartikan sebagai latihan mental, moral, dan fisik yang bisa menghasilkan manusia berbudaya tinggi maka pendidikan berarti menumbuhkan personalitas (kepribadian) serta menanamkan rasa tanggung jawab. Pendidikan Islam ialah bimbingan yang dilakukan oleh seorang dewasa kepada anak didik dalam masa pertumbuhan, agar ia memiliki kepribadian muslim. Ilmu pendidikan islam ialah ilmu yang membicarakan persoalan-persoalan pokok pendidikan islam dan kegiatan mendidik anak untuk ditujukan ke arah terbentuknya kepribadian muslim. Pendidikan islam dapat dirumuskan sebagai berikut "proses transinternalisasi pengetahuan dan nilai islam kepada peserta didik melalui upaya pengajaran, pembiasaan, bimbingan, pengasuhan, dan pengembangan potensinya, guna mencapai keselarasan dan kesempurnaan hidup didunia dan akhirat."

\section{Tahap Sebelum Menikah (Pemilihan Jodoh)}

Fase ini adalah persiapan bagi seseorang yang sudah dewasa untuk menghadapi hidup baru yaitu berkeluarga. Salah satu pendidikan yang dimiliki oleh seseorang yang sudah dewasa itu adalah masalah pemilihan jodoh yang tepat. Sebab masalah ini mempengaruhi terhadap kebahagian rumah tangganya dikemudian hari. Selain memantapkan hati mengenai calon pasangan yang sah, sangat perlu pula untuk memilih kriteria pasangan dalam menikah dan hidup bahagia selamanya, ada beberapa hal yang penting menjadi persiapan sebelum menikah. Menikah bukanlah hal yang mudah dilalui, harus memiliki beberapa pertimbangan dan jawaban sebelum masuk ke jenjang yang lebih serius dengan pasangan. Pendidikan Pra Konsepsi ini adalah salah satu upaya persiapan pendidikan yang dimulai ketika seseorang memilih pasangan hidupnya sampai pada saat setelah terjadinya pembuahan dalam rahim sang Ibu. Dalam kaitannya dengan hal ini, Islam telah mengajarkan hal-hal berikut:

a. Dalam memilih pasangan hidup, Islam mengajarkan agar mengutamakan pengetahuan agamanya yang sama-sama beragama Islam, dan juga memiliki perangai dan tingkah laku yang baik. Rasulullah SAW bersabda, yang artinya :

"Wanita itu dinikahi karena empat hal, yaitu karena kekayaannya, kecantikannya, keturunannya, dan karena agamanya, kamu pasti akan bahagia." 
Berdasarkan hadits ini, sangatlah jelas bahwa kita memilih calon pasangan hidup, agama dan akhlak merupakan dua hal yang paling utama. Setelah kedua hal ini barulah faktor-faktor lain dipertimbangkan.

b. Mencari rejeki dan makanan yang halal. Seperti disebutkan dalam Q.S. An-Nahl : 114, yang artinya :

"Maka makanlah yang halal lagi baik dari rejeki yang telah diberikan Allah kepadamu; dan syukurilah nikmat Allah, jika kamu hanya kepada Nya saja menyembah."

Paparan ayat di atas memmberikan pemahaman bahwa apa yang kita konsumsi seharihari itu memiliki pengaruh yang sangat besar terhadap keturunan, baik itu fisik maupun mental. Selain itu, menurut disiplin ilmu biologi, makanan yang baik dan bergizi itu memiliki pengaruh yang besar terhadap pematangan ovum dan spermatozoa yang kemudian akan menjadi janin yang sehat dan kuat.

Rasulullah SAW telah memberikan gambaran dalam haditsnya mengenai pemilihan calon istri atau suami. Berikut ini adalah beberapa hadits yang berkenaan dengan pemilihan jodoh diantaranya:

\section{1) Pemilihan Calon Istri}

Sabda Rasulullah SAW yang artinya : "Dunia ini adalah perhiasan, sebaik-baiknya perhiasan adalah wanita yang shalehah." (HR. Muslim).

Dari penjelasan hadits Rasulullah di atas, maka dapatlah diambil beberapa syarat yang penting untuk memilih calon istri diantaranya:

a) Saling mencintai antara calon kedua mempelai.

b) Memilih wanita karena agamanya agar nantinya mendapat berkah dari Allah SWT.

c) Wanita yang sholehah.

d) Sama derajatnya dengan calon mempelai.

e) Wanita yang hidup dilingkungan yang baik.

f) Wanita yang jauh keturunannya dan jangan memilih wanita yang dekat sebab dapat menurunkan anak yang lemah jasmani dan memiliki IQ yang rendah.

g) Wanita yang gadis dan subur (bisa melahirkan) lebih diutamakan.

\section{2) Pemilihan Calon Suami}

Sebagaimana agama Islam memberikan perhatian saksama terhadap pemilihan seorang calon istri, demikian pula halnya perempuan terhadap pemilihan seorang calon suami. Pada keduanya, hal yang perlu diperhatikan adalah keterikatannya dengan akhlak agama. Muhammad Bagir dalam buku Muamalah Menurut Alquran, Sunah, dan Para Ulama menjelaskan, apabila kuat agama seseorang, maka niscaya dia akan memuliakan istrinya dan tidak akan pernah menzaliminya, meskipun di saat dia tidak mencintainya. Penulis kemukakan beberapa di antaranya adalah sebagaimana hadis Nabi Muhammad SAW dari Ibnu Abbas RA:

"Sebaik-baik kalian adalah orang yang paling baik bagi keluarganya. Dan aku (Nabi Muhammad) yang paling baik bagi keluargaku." (HR at-Tirmidzi)

Tentang memilih calon suami, Imam AlGhazali berpendapat adalah wajib hukumnya bagi seorang wali (ayah atau anggota keluarga lainnya yang bertanggung jawab atas diri seorang perempuan) menilai dengan seksama sifat-sifat yang disandang oleh seorang calon suami. Maka siwali, menurut Imam Al-Ghazali, ditekankan untuk memilihkan calon suami yang terbaik bagi putri atau saudara perempuannya. Bahkan, Rasulullah SAW bersabda:

"Apabila kamu sekalian didatangi seseorang yang agama dan akhlaknya kamu ridhai, maka kawinkanlah ia. Jika kamu sekalian tidak melaksanakannya maka akan menjadi fitnah dimuka bumi ini dan tersebarlah kerusakan." (HR. Tirmidzi).

Berdasarkan hadits tersebut, maka jelaslah bahwa hal yang paling penting dalam memilih calon suami adalah melihatnya dari sudut pandang agama yang dianutnya dan akhlak yang dimilikinya.

\section{Tahap Perkawinan/Pernikahan}

Perkawinan adalah hubungan permanen antara laki-laki dan perempuan yang diakui sah oleh masyarakat dan agama yang bersangkutan yang berdasarkan atas peraturan perkawinan yang berlaku. Bentuk perkawinan tergantung budaya setempat bisa berbeda-beda dan tujuannya bisa berbeda-beda juga. Tapi umumnya perkawinan itu ekslusif dan mengenal konsep perselingkuhan sebagai pelanggaran terhadap perkawinan. Perkawinan umumnya dijalani dengan maksud untuk membentuk keluarga. Ikatan perkawinan yang sah dibuktikan dengan adanya dokumen berupa akta perkawinan.

Beberapa aspek yang dijelaskan oleh syariat Islam yang berhubungan dengan anjuran pernikahan/perkawinan antara lain :

1) Perkawinan merupakan Sunnah Rasul, dengan sabdanya:

"Siapa saja yang mampu menikah, namun ia tidak menikah, maka tidaklah termasuk dalam golonganku." (HR. Thabrani dan Baihaki).

2) Perkawinan untuk ketentraman kasih sayang, dengan Firman-Nya:

"Dan diantara tanda-tanda kekuasaan-Nya ialah, dia menciptakan untukmu istri-istri dari 
jenismu sendiri supaya kamu cendrung tentram kepada-Nya. Dan dijadikannya diantara kamu rasa kasih sayang. Sesungguhnya yang demikian itu benar-benar terdapat tanda-tanda bagi kaum yang berpikir." (QS. Ar-Rum : 21).

3) Perkawinan untuk mendapatkan keturunan

Mendapatkan keturunan yang sehat, pintar, sholeh sholehah, dan menggemaskan merupakan dambaan dan salah satu tujuan dari pernikahan. Oleh sebab itu, sebelum menikah, alangkah baiknya Anda dan pasangan melakukan tes kesehatan atau kesuburan untuk mengetahui kondisi kesehatan dari kedua belah pihak. Bagaimana anak memasukkan ayah dan ibunya kedalam Surga, Mari kita mencermati bagaimana jawabannya dari Rasulullah SAW dalam hadits Qudsi. Imam Ahmad meriwayatkan dari sebagian Sahabat Nabi Shallalla'alaihi Wassalam, bahwa beliau bersabda:

"Di perintahkan kepada anak-anak di Surga: 'Masuklah kedalam Surga.' Mereka menjawab: "Wahai Rabb-ku (kami tidak masuk) hingga bapak dan ibu kami masuk (terlebih dahulu).' ketika mereka (bapak dan ibu) datang, maka Allah Azza wa Jalla berfirman kepada mereka: aku tidak melihat mereka terhalang. Masuklah kalian kedalam Surga.' Mereka mengatakan: Wahai Rabb-ku, bapak dan ibu kami?' Allah berfirman: 'Masuklah kedalam Surga bersama orang tua kalian."

4) Perkawinan untuk memelihara pandangan dan menjaga kemaluan dari kemaksiatan. AtTirmidzi meriwayatkan dari Abu Hurairah Radhiyallahu anhu, bahwa Rasulullah SAW bersabda:

"Ada tiga golongan yang pasti akan ditolong oleh Allah; seorang budak yang ingin menebus dirinya dengan mencicil kepada tuannya, orang yang menikah karena ingin memelihara kesuciannya, dan pejuan di jalan Allah."

Setelah itu calon dipilih, diadakan peminangan dan selanjutnya dilaksanakan pernikahan dengan Walimatul Al-Ursy nya.

\section{Tahap Kehamilan}

Salah satu tujuan berumah tangga adalah untuk mendapatkan keturunan, karena itu seorang istri mengharapkan ia dapat melahirkan seorang anak. Sebagai tanda seorang istri akan memiliki anak adalah melalui proses kehamilan selama lebih kurang 9 bulan. Wanita mengalami siklus menstruasi setiap bulannya. Ketika siklus bulanan tersebut berhenti, bisa jadi itu tanda awal kehamilan. Kendati demikian, ibu hamil terkadang masih bisa mengalami gejala mirip menstruasi, hanya saja jumlah darah yang keluar sangat sedikit. Masa kehamilan memiliki beberapa tahapan, yaitu:

1) Tahapan Nuthfah: Pada tahap ini, calon anak masih dalam bentuk cairan sperma dan sel telur. Tahap ini berlangsung selama 40 hari.

2) Tahap 'Alaqah: Tahapan ini tentunya terjadi setelah janin berumur dalam 80 hari, cairan tersebut berkembang bagaikan segumpal darah kental dan bergantung pada dinding rahim ibu.

3) Tahap Mudghah: Tahapan ini terjadi pada saat janin berumur 120 hari, segumpal darah tadi berkembang menjadi segumpal daging. Pada masa inilah, calon bayi telah siap menerima hembusan ruh dari Malaikat utusan Allah.

Ada tiga faktor yang perlu dibicarakan berkaitan dengan proses pendidikan. Pertama diyakini bahwa periode ini berawal dari adanya kehidupan. Hal ini dinyatakan dengan adanya perkembangan yang berawal dari nuthfah sampai menjadi mudhgah, dan kemudian menjadi seorang bayi; Kedua, setelah berbentuk daging (mudghah), Allah mengutus malaikat untuk meniupkan ruh kepadanya. Tampaknya, ruh inilah yang menjadi tahap awal bergeraknya kehidupan psikis manusia. Disisi lain, perkembangan psikis manusia juga dipengaruhi oleh kegembiraan ataupun penderitaan yang dialami oleh sang ibu. Kebahagian, kelincahan ataupun kesedihan, kemurungan yang ditujukkan oleh sang ibu ketika mengandung akan tercermin kepada tingkah laku bayi yang dilahirkan. Ketiga, aspek yang paling penting adalah aspek agama. Naluri agama sebenarnya sudah ada pada setiap individu jauh sebelum kelahirannya didunia nyata.

Menurut Zakiah Daradjad, proses pendidikan lebih berpengaruh kepada anak apabila diamalkan langsung orang tuanya selama janin berada dalam kandungan. Kontak psikis secara langsung antara orang tua, terutama ibu dengan janin sebenarnya disebut pendidikan pada masa kehamilan.

\section{PERKEMBANGAN PASCANATAL DALAM PENDIDIKAN ISLAM (TARBIYAH BA'DA AL-WILADAH)}

Pendidikan pascanatal yaitu pendidikan yang dimulai sejak lahirnya anak sampai mereka dewasa, bahkan sampai meninggal dunia yang kita kenal dengan sebutan pendidikan seumur hidup. Dalam upaya pengembangan pendidikan agama dalam keluarga, Rasulullah SAW telah memberikan tuntunan kepada kita agar mendidik anak sesuai 
dengan perkembangan jiwanya. Ada beberapa tahapan dengan perkembangan jiwa anak yaitu:

\section{Fase bayi Usia anak 0-3 tahun}

Pada masa anak usia 0-3 tahun yang dapat dilakukan kedua orang tua adalah memberikan suasana kehidupan yang agamis seperti yang dianjurkan oleh Rasulullah SAW, seperti:

1) Membaca adzan pada telinga kanan dan iqamat pada telinga kiri sang bayi pada saat baru dilahirkan.

2) Menaqiqahkannya, disamping sebagai rasa syukur atas kelahiran anak, juga mengajarkan kepada anak agar suka bersedekah dan pandai bersyukur dikemudian hari dalam menjalani kehidupannya.

3) Memberikan nama kepada anak dengan nama yang baik.

4) Anak dicukur rambutnya / dibersihkan dari kotorannya.

5) Setelah sampai usia 3 tahun, hendaknya selalu diberikan suasana agamis dan dibiasakan dengan kebaikan semisal memperdengarkan bacaan AlQur'an kepadanya.

Selama rentang waktu itu, kehidupan bayi biasanya sangat tergantung pada bantuan dan pemeliharaan pihak lain, terutama siibu. Peranan ibu yang demikian besarnya terhadap si bayi itu tentu mempunyai arti tersendiri bagi pendidikannya. Fase bayi sudah dapat dikatakan lebih empirik. Proses pendidikan pada masa pranatal bersifat tidak langsung, maka pada masa bayi sudah mulai masuk ke dalam pendidikan yang langsung. Pada diri sang bayi sudah terdapat beberapa aspek kehidupan yang researchable. Beberapa data aspek kehidupan sudah mampu dilacak dimonitor melalui indera. Hal ini semua menunjukkan bahwa sibayi pada saat itu walau masih belum sempurna kerja organ tubuhnya, namun sudah siap menerima pendidikan

Adapun tahapan perkembangan menurut Piaget yakin setiap bayi melalui beberapa tahap dalam memahami dunia. Masing-masing tahap terkait dengan usia dan terdiri dari cara berfikir yang khas/berbeda. Tahapan perkembangan kognitif menurut Piaget adalah sebagai berikut:

Tahap Sensori Motor: Tahap ini merupakan tahap pertama. Tahap ini dimulai sejak lahir sampai usia 2 tahun. Pada tahap ini, bayi membangun suatu pemahaman tentang dunia dengan mengkoordinasikan pengalamanpengalaman sensor (seperti melihat dan mendengar) dengan tindakan-tindakan fisik.

Dengan berfungsinya alat-alat indera serta kemampuan kemampuan-kemampuan melakukan gerak motorik dalam bentuk refleks ini, maka seorang bayi berada dalam keadaan siap untuk mengadakan hubungan dengan dunianya. Piaget membagi tahap sensori motor ini kedalam 6 periode, yaitu:

a. Periode 1: Penggunaan Refleks-Refleks (Usia 01 bulan)

Refleks yang paling jelas pada periode ini adalah refleks menghisap (bayi otomatis menghisap kapanpun bibir mereka disentuh) dan refleks mengarahkan kepala pada sumber rangsangan secara lebih tepat dan terarah. Misalnya jika pipi kanannya disentuh, maka ia akan menggerakkan kepala kearah kanan.

b. Periode 2: Reaksi Sirkuler Primer (Usia 1-4 bulan)

Reaksi ini terjadi ketika bayi menghadapi sebuah pengalaman baru dan berusaha mengulanginya. Contoh: menghisap jempol. Pada contoh menghisap jempol, bayi mulai mengkoordinasikan, pertama Gerakan motorik dari tangannya dan kedua Penggunaan fungsi penglihatan untuk melihat jempol.

c. Periode 3: Reaksi Sirkuler sekunder (Usia 4-10 bulan)

Reaksi sirkuler primer terjadi karena melibatkan koordinasi bagian-bagian tubuh bayi sendiri, sedangkan reaksi sirkuler sekunder terjadi ketika bayi menemukan dan menghasilkan kembali peristiwa menarik diluar dirinya.

d. Periode 4: Koordinasi skema-skema skunder (Usia 10-12 bulan)

Pada periode ini bayi belajar untuk mengkoordinasikan dua skema terpisah untuk mendapatkan hasil. Contoh: suatu hari Laurent (anak Piaget) ingin memeluk kotak mainan, namun Piaget menaruh tangannya ditengah jala. Pada awalnya Laurent mengabaikan tangan ayahnya. Dia berusaha menerobos atau berputar mengelilinginya tanpa menggeser tangan ayahnya. Ketika Piaget tetap menaruh tangannya untuk menghalangi anaknya, Laurent terpaksa memukul kotak mainan itu sambil melambaikan tangan, mengguncang tubuhnya sendiri dan mengibaskan kepalanya dari satu sisi ke sisi lain. Akhirnya setelah beberapa hari mencoba, Laurent berhasil menggerakkan perintang dengan mengibaskan tangan ayahnya dari jalan sebelum memeluk kotak mainan. Dalam kasus ini, Laurent berhasil mengkoordinasikan dua skema terpisah yaitu: 1). Mengibaskan perintang 2). Memeluk kotak mainan.

e. Periode 5: Reaksi Sirkuler Tersier (Usia 12-18 bulan)

Pada periode 4, bayi memisahkan dua tindakan untuk mencapai satu hasil tunggal. Pada periode 5 ini bayi bereksperimen dengan tindakantindakan yang berbeda untuk mengamati hasil 
yang berbeda-beda. Contoh: Suatu hari Laurent tertarik dengan meja yang baru dibeli Piaget. Dia memukulnya dengan telapak tangannya beberapa kali. Kadang keras dan kadang lembut untuk mendengarkan perbedaan bunyi yang dihasilkan oleh tindakannya.

f. Periode 6: Permulaan Berfikir (Usia 18-24 bulan)

Pada periode 5 semua temuan-temuan bayi terjadi lewat tindakan fisik, pada periode 6 bayi kelihatannya mulai memikirkan situasi secara lebih internal sebelum pada akhirnya bertindak. Jadi, pada periode ini anak mulai bisa berfikir.dalam mencapai lingkungan, pada periode ini anak sudah mulai dapat menentukan cara-cara baru yang tidak hanya berdasarkan rabaan fisis dan internal, tetapi juga dengan koordinasi internal dalam gambaran atau pemikirannya.

\section{Fase Pra Sekolah (4-6 tahun)}

Dari segi fisik, anak sudah relatif kuat dan lincah. Sedangkan dari segi psikis harus dilihat bahwa kenakalan anak berkaitan erat dengan berkembangnya sifat dinamis, kreatif, dan puas dengan sesuatu yang telah ada. Anak-anak pada usia ini bersifat meniru, banyak bermain denga lelakon (sandiwara) atau khayalan, yang kadangkadang dapat membantu dalam mengatasi kekurangan-kekurangannya dalam kenyataan. Kegiatan yang bermacam-macam itu akan memberikan keterampilan pada pengalamanpengalaman si anak. Maka perlakuan kita pada anak usia ini hendaknya tetap, tak ada kegoncangan.

Dalam mendidik anak usia ini, orang tua harus mengambil jalan tengah, jangan terlalu lunak dan jangan terlalau ekstim. Orang tua harus memahami potensi-potensi yang dimiliki oleh anak semasa itu. Fitrah merupakan modal bagi seorang bayi, sebagai mana yang telah dijelaskan untuk menerima agama tauhid dan tidak akan berbeda antara bayi yang satu dengan bayi yang lainnya. Oleh sebab itu orang tua sebagai pendidik berkewajiban melakukan sebagai berikut:

1) Membiasakan anak untuk mengingat kebesaran dan nikmat Allah, serta semangat mencari dalil mengesakan Allah, melalui tandatanda kekuasaannya dan menginterpretasikan berbagai gejala alam melalui penafsiran yang dapat mewujudkan tujuan pengokohan fitrah anak agar tetap berada dalam kesucian dan kesiapan untuk mengagungkan Allah.

2) Rasa kagum anak terhadap ayahnya dapat dipergunakan oleh ayahnya untuk membina mental anaknya dengan kasih sayangnya, kearah pengenalan Tuhan.
Adapun menurut Piaget tahap ini dikenal dengan Tahap Pemikiran Pra-Operasional: Pada tahap ini anak mulai melukiskan dunia dengan kata-kata dan gambar-gambar atau simbol.Menurut Piaget, walaupun anak-anak pra sekolah dapat secara simbolis melukiskan dunia, namun mereka masih belum mampu untuk melaksanakan " Operation (operasi)", yaitu tindakan mental yang diinternalisasikan yang memungkinkan anak-anak melakukan secara mental yang sebelumnya dilakukan secara fisik.

Perbedaan tahap ini dengan tahap sebelumnya adalah " kemampuan anak mempergunakan simbol”. Penggunaan simbol bagi anak pada tahap ini tampak dalam lima gejala berikut:

a) Imitasi tidak langsung: Anak mulai dapat menggambarkan sesuatu hal yang dialami atau dilihat, yang sekarang bendanya sudah tidak ada lagi.Jadi pemikiran anak sudah tidak dibatasi waktu sekarang dan tidak pula dibatasi oleh tindakan-tindakan indrawi sekarang.

b) Permainan Simbolis: Sifat permainan simbolis ini juga imitatif, yaitu anak mencoba meniru kejadian yang pernah dialami.

c) Menggambar: Pada tahap ini merupakan jembatan antara permainan simbolis dengan gambaran mental. Unsur pada permainan simbolis terletak pada segi "kesenangan" pada diri anak yang sedang menggambar. Sedangkan unsur gambaran mentalnya terletak pada "usaha anak untuk memulai meniru sesuatu yang riel".

d) Gambaran Mental: Merupakan penggambaran secara pikiran suatu objek atau pengalaman yang lampau.Gambaran mental anak pada tahap ini kebanyakan statis. Anak masih mempunyai kesalahan yang sistematis dalam mengambarkan kembali gerakan atau transformasi yang ia amati.

e) Bahasa Ucapan: Anak menggunakan suara atau bahasa sebagai representasi benda atau kejadian. Melalui bahasa anak dapat berkomunikasi dengan orang lain tentang peristiwa kepada orang lain.

\section{Fase Anak-Anak (6 - 12 tahun)}

Periode ini merupakan masa sekolah dasar, artinya pada masa ini anak harus mulai dibekali pengetahuan-pengetahuan dasar yang tentunya dianggap penting untuk keberhasilan anak dikemudian hari. Adapun materi pendidikannya harus disesuaikan dengan tingkat kemampuan dan perkembangan kejiwaan anak. Di antara materi mendesak untuk diberikan pada anak ialah masalah keimanan, membaca Al Quran, 
melaksanakan shalat, puasa, dan akhlak. Sebenarnya yang terpenting yaitu orientasi penanaman nilai dan pembentukan sikap keagamaan. Tentunya model penyampaian dan penanamannya harus dimulai dari yang sederhana terlebih dahulu, kemudian secara berangsurangsur dibawa kepada penyempurnaan. Dalam upaya pendidikan Islam, Rasulullah telah mengajarkan pada hadits yang artinya:

"Suruhlah anak-anak melakukan ibadah shalat pada usia 7 tahun dan bilamana sampai usia 10 tahun belum shalat, maka pukullah ia. Dan pisahkan tempat tidurnya."

Pada usia sekolah ini anak sudah berhubungan dengan teman dalam kelompok bermain. Kelompok bermain ini dapat dimanfaatkan untuk menanamkan pendidikan islam. Metode pendidikan agama dapat diberikan dengan metode keteladanan, pembiasaan, dan latihan, kemudian secara berangsur-angsur diberikan penjelasan secara logis maknawi. Memperkenalkan sifat-sifat Allah kepada anakanak pada umur ini hendaknya memiliki sifat-sifat Allah yang menyenangkan baginya seperti Allah Maha Pengasih. Sifat-sifat Allah yang menakutkan seperti menghukum, mengazab, janganlah diajarkan dulu karena hal tersebut dapat menimbulkan anak takut dan benci kepada Allah, akibatnya anak menjauhkan diri dari Allah.

Sedangkan menurut Piaget tahap ini dikenal dengan Tahap Operasi berfikir Kongkret tahap ini dicirikan dengan perkembangan system pemikiran yang didasarkan pada aturan-aturan yang logis. Anak sudah mengembangkan operasi logis. Prosesproses penting selama tahapan ini adalah:

a. Pengurutan; Yaitu kemampuan untuk mengurutkan objek menurut ukuran, bentuk, atau ciri lainnya.Contohnya, bila diberi benda berbeda ukuran, mereka dapat mengurutkannya dari benda yang paling besar ke yang paling kecil.

b. Klasifikasi; Kemampuan untuk memberi nama dan mengidentifikasi serangkaian benda menurut tampilannya, ukurannya, atau karakteristik lain, termasuk gagasan bahwa serangkaian benda-benda dapat menyertakan benda lainnya ke dalam rangkaian tersebut. Anak tidak lagi memiliki keterbatasan logika berupa animisme (anggapan bahwa semua benda hidup dan berperasaan).

c. Decentering; Anak mulai mempertimbangkan beberapa aspek dari suatu permasalahan untuk bisa memecahkannya. Sebagai contoh anak tidak akan lagi menganggap gelas lebar tapi pendek lebih sedikit isinya dibanding gelas kecil yang tinggi. d. Reversibility; Anak mulai memahami bahwa jumlah atau benda-benda dapat diubah, kemudian kembali ke keadaan awal. Untuk itu, anak dapat dengan cepat menentukan bahwa 4+4 sama dengan 8, 8-4 akan sama dengan 4, jumlah sebelumnya.

e. Konservasi; Memahami bahwa kuantitas, panjang, atau jumlah benda-benda adalah tidak berhubungan dengan pengaturan atau tampilan dari objek atau benda-benda tersebut. Sebagai contoh, bila anak diberi gelas yang seukuran dan isinya sama banyak, mereka akan tahu bila air dituangkan ke gelas lain yang ukurannya berbeda, air di gelas itu akan tetap sama banyak dengan isi gelas lain.

f. Penghilangan sifat Egosentrisme; Kemampuan untuk melihat sesuatu dari sudut pandang orang lain (bahkan saat orang tersebut berpikir dengan cara yang salah). Sebagai contoh, Lala menyimpan boneka di dalam kotak, lalu meninggalkan ruangan, kemudian Baim memindahkan boneka itu ke dalam laci, setelah itu baru Lala kembali ke ruangan. Anak dalam tahap operasi konkrit akan mengatakan bahwa Lala akan tetap menganggap boneka itu ada di dalam kotak walau anak itu tahu bahwa boneka itu sudah dipindahkan ke dalam laci oleh Baim.

\section{Fase Remaja (12-21)}

Masa ini berlangsung dari umur 12 sampai 21 tahun. Awal remaja ditandai dengan dimulainya keguncangan, baik bagi laki-laki maupun perempuan. Masa remaja ini ditandai dengan adanya peubahan-perubahan gender. Pada masa ini remaja membutuhkan teman yang dapat memahaminya dan menolongnya, teman yang dapat turut serta merasakan suka dukanya. Disisni mulai tumbuh dorongan untuk mencari pedoman hidup, mencari sesuatu yang dapat dipandang bernilai, pantas dijunjung tinggi, dipuja-puja. Proses pembentukan pendirian hidup atau pendangan hidup atau cita-cita ini dapat dipandang sebagai penemuan nilai-nilai hidup didalam eksplorasi si remaja.

Remaja pada fase ini semakin mampu dan memahami nilai-nilai norma-norma yang berlaku dalam kehidupan. Untuk itulah periode ini terjadi sangat baik untuk membantu remaja guna menumbuhkan sikap bertanggung jawab dan memahami nilai-nilai terutama yang bersumber dari agama islam. Dalam konsep sederhana mereka perlu dikenalakan konsep agama tentang sikap yang baik, rasa bertanggung jawab didalam kehidupan untuk mencapai keselamatan di dunia dan akhirat. 
Tanggung jawab orang tua terhadap pendidikan anak telah di terangkan dalam firman Allah SWT: "Wahai orang-orang yang beriman, jagalah dirimu dan keluargamu dari api neraka".

Setelah awal masa remaja berlalu anak memasuki rasa pubertas. Pada masa ini tampak kecenderungan anak remaja kembali kepada sikap introverts. Karena anak mengira dirinya sudah dewasa, hal ini sering mempersulit upaya memberikan bimbingan dan petunjuk kepada mereka. Najib Khalil al-Amin menyebutkan bahwa dalam mendidik anak harus mengambil sikap sebagai berikut:

1) Mengetahui perubahan-perubahan yang terjadi pada anak-anak mereka yang sedang puber dengan melakukan pengamatan.

2) Mengarahkan mereka untuk selalu pergi ke masjid sejak kecil sehingga memiliki disiplin naluriah dan andil yang potensial oleh lingkungan rabbaniah.

3) Menanamkan rasa percaya diri pada diri mereka dan siap mendengarkan pendapatpendapat mereka.

4) Menyarankan agar menjalani persahabatan dengan teman-teman yang baik. Mengembangkan potensi mereka disemua bidang yang bermanfaat.

5) Menganjurkan mereka untuk berpuasa sunat karena hal itu dapat menjadi perisai dari kebobrokan moral.

6) Membuka dialog dan menyadarkan mereka akan status sosial mereka

Yang paling mendasar dan sangat prioritas dalam upaya mendidik anak puer terkait dengan pendidikan agama adalah mengontrol dan mengawasi semua aktivitas yang dilakukan, khususnya saat kontroling terhadap penggunaan media yang akhir-akhir ini sangat marak yang tidak menutup kemungkinan akan menjerumuskan kehidupan anak ke dalam hal yang tidak diinginkan. Betapa besarnya dampak media, baik massa atau elekronika atau yang dikenal dengan sebutan IT (Informasi Telekomunikasi), seperti media telepon seluler, televisi, internet dan lain sebagainya yang sering menyajikan sistus-situs porno dan website-website yang sering memberikan orientasi yang bersifat bisnis ketimbang agama. Hal ini sangat buruk bagi masa depan anak. Perhatian dan kontrol orang tua adalah satu-satunya antisipatip yang ampuh dalam hal menangkal pengaruh-pengaruh negatif ini. Di samping media yang bersifar online, tak kalah pentingnya media ofline sering juga mempengaruhi kehidupan anak atau remaja. Misalnya pergaulan kekinian yang telah banyak dipengaruhi oleh budaya-budaya asing yang sangat bertentangan dengan agama dan akhlakul karimah.

\section{Fase Dewasa}

Pada umumnya ketika seseorang telah mencapai usia dewasa, dia sudah mempunyai banyak ilmu pengetahuan dan pengalaman. Sedangkan selainnya mereka langsung berhadapan dengan masalah pekerjaan, masalah kemasyarakatan dan perkawinan. Atas dasar itu, pendidikan yang diberikan pada mereka harus sesuai dengan situasi dan kondisinya. Pendidikan agama islam bagi mereka masih dibutuhkan. Usia dewasa dimulai sejak berakhirnya kegoncangankegoncangan kejiwaan yang menimpa masa remaja. Dengan demikian, usia dewasa bisa dikatakan ketenangan jiwa, ketetapan hati dan keimanan yang tegas. Sejalan dengan tingkat perkembangan usianya, Jalaluddin mengatakan sikap keagamaan pada orang dewasa memiliki ciriciri yaitu:

1) Menerima kebenaran agama berdasarkan pertimbangan yang matang bukan sekedar ikut-ikutan.

2) Cenderung bersifat realistis sehingga normanorma agama lebih banyak diaplikasikan dalam sikap dan tingkah laku.

3) Bersikap positif terhadap ajaran dan normanorma agama dan berusaha untuk mempelajari dan memperdalam keagamaan.

4) Tingkat ketaatan beragama didasarkan atas pertimbangan dan tanggung jawab diri, hingga keberagamaan merupakan realisasi dari sikap hidup.

5) Bersikap lebih terbuka dan wawasan yang luas.

6) Bersikap lebih kritis terhadap materi ajaran agama sehingga kemantapan beragama selain didasarkan atas pertimbangan pemikiran juga didasarkan atas pertimbangan hati nurani.

7) Sikap keberagamaan cendrung mengarah kepada tipe-tipe kepribadian masing-masing sehingga terlihat adanya pengaruh kepribadian dalam menerima, memahami serta melaksanakan ajaran agama yang diyakininya.

Pada perkembangan usia remaja Elizabeth B. Hurlock membagi masa dewasa menjadi tiga yaitu: masa dewasa awal, masa dewasa madya, masa usia lanjut. Klasifikasi senada juga diungkap oleh Lewis Sherril yang membagi masa remaja sebagai berikut:

a. Masa Dewasa Awal, masa ini remaja ada kecendrungan memilih arah hidup dengan menghadapi godaan berbagai kemungkinan pilihan.

b. Masa Dewasa Tengah, pada masa ini sudah mulai menghadapi tantangan hidup. Pada masa 
ini adalah masa dimana sudah mencapai pandangan hidup yang matang dan utuh yang dapat menjadi dasar dalam membuat keputusan yang konsisten.

c. Masa Dewasa Akhir yang ciri utamanya adalah pasrah

Manusia disebut makhluk yang memiliki prinsip tanpa daya, karena untuk perkembangan dan pertumbuhan secara normal manusia memerlukan bantuan dari luar dirinya. Bantuan yang dimaksud antara lain dalam bentuk bimbingan dan pengarahan dari lingkungannya. Bimbingan dan pengarahan yang diberikan dalam membantu perkembangan tersebut pada hakekatnya diharapkan sejalan dengan kebutuhan manusia itu sendiri, yang sudah tersimpan sebagai potensi bawaan. Agar efektif maka manusia harus menjalani tahapan-tahapan hidupnya dengan baik.

Dalam suatu periode hidup manusia, terdapat fase-fase tertentu yang dilewati antara lain: fase pranatal, bayi baru lahir, masa bayi, masa kanak-kanak, masa anak-anak, masa puber, masa remaja, masa dewasa, masa usia madya dan masa usia lanjut. Salah satu fase yang paling sering dibicarakan dan menarik perhatian para psikolog adalah fase madya dan fase lanjut usia (manula). Hal ini dikarenakan timbulnya karakter dan kebiasaan unik yang dimiliki oleh seseorang ketika memasuki usia lanjut yaitu berkisar antara umur 70-100 tahun atau sampai meninggal.

Perkembangan jiwa agama pada usia lanjut terdapat pada masa awal, tengah dan akhir. Dalam perkembangannya manusia membutukan bantuan baik itu dari dalam dan dari luar seperti bimbingan dan pengarahan dari lingkungannya. Karakteristik Keberagaman di Usia Lanjut Secara garis besar karakteristik keberagaman pada usia lanjut adalah sebagai berikut:

a) Kehidupan keagamaan pada usia lanjut telah mencapai tingkat kemantapan / kematangan beragama.

b) Meningkatnya kecendrungan untuk menerima pendapat keagamaan.

c) Mulai muncul pergaulan terhadap realitas tentang kehidapan akhirat secara lebih bersungguh-sungguh.

d) Sikap keberagamaan cendrung mengarah kepada kebutuhan saling cinta antara sesama manusia secara sifat-sifat luhur.

e) Timbul rasa takut kepada kematian yang meningkat sejalan dengan pertambahan usia lanjut.

f) Perasaan takut kematian yang berdampak pada peningkatan pembentukan sikap keagamaan dan kepercayaan terhadap kehidupan abadi (akhirat). g) Perlakuan Terhadap Usia Lanjut Menurut Islam Manusia usia lanjut dalam penilaian banyak orang adalah manusia yang sudah tidak produktif lagi.

Kondisi fisik rata-rata sudah menurun, sehingga dalam kondisi yang sudah uzur ini berbagai penyakit siap untuk menggerogoti mereka. Dengan demikan, di usia lanjut ini terkadang muncul semacam pemikiran bahwa mereka berbeda pada sisa-sisa umur menunggu datangnya kematian. Lain halnya konsep yang dianjurkan dalam Islam. Perlakuan terhadap orang tua yang berusia lanjut dibebankan kepada anakanak mereka, bukan kepada badan atau panti asuhan, termasuk panti jompo. Perlakuan terhadap orang tua menurut tuntunan Islam berawal dari rumah tangga. Allah menyebutkan pemeliharaan secara khusus orang tua yang sudah lanjut usia dengan memerintahkan kepada anak-anak mereka untuk memperlakukan kedua orang tua mereka dengan kasih sayang.

Menurut As-Shobuny, yang dimaksud dengan firman Allah yang artinya:

"Barang siapa kami panjangkan umurnya, niscaya kami kembalikan dia kepada kejadian (nya). Maka apakah mereka tidak memikirkannya." (QS. Yasin : 68).

Firman Allah SWT di atas menggambarkan bagaimana perlakuan terhadap manusia usia lanjut menurut Islam. Manusia usia lanjut dipandang tak ubahnya seorang bayi yang memerlukan pemeliharaan dan perawatan serta perhatian khusus dengan penuh kasih sayang. Perlakuan yang demikian itu tidak dapat diwakilkan kepada siapapun, melainkan menjadi tanggung jawab anak-anak mereka. Perlakuan yang baik dan penuh dengan kesabaran serta kasih sayang dinilai sebagai bakti padanya. Sebaliknya perlakuan yang tercela dinilai sebagai kedurhakaan. Perlakuan terhadap manusia usia lanjut menurut Islam merupakan kewajiban agama, maka sangat tercela dan dipandang durhaka bila seorang anak tega menempatkan orang tuanya ditempat penampungan atau panti jompo, alasan apapun tidak dapat diterima bagi perlakuan itu.

\section{KESIMPULAN}

Pendidikan Islam masa pranatal disebut juga dalam bahasa arab tarbiyah qabl al-wiladah, pendidikan pranatal adalah pendidikan sebelum masa melahirkan yang ditandai dengan fase pemilihan jodoh, pernikahan, dan kehamilan. kemudian berlanjut kepada fase pendidikan Islam masa pascanatal atau tarbiyah ba'da al-wiladah, pendidikan pascanatal yaitu pendidikan yang dimulai sejak lahirnya anak sampai mereka 
dewasa, bahkan sampai meninggal dunia yang kita kenal dengan sebutan pendidikan seumur hidup. Masa pranatal ini sangat penting artinya karena ia merupakan awal dari kehidupan. Masa kehamilan ini sangat penting artinya, karena merupakan awal kehidupan. Didalam rahim setiap janin terlindung dari semua pengaruh kondisi luar kecuali yang dapat sampai melalui ibu yang mengandungnya. Rasa aman dan perlindungan itu tidak akan pernah ditemui anak setelah ia lahir. Pendidikan pascanatal memiliki beberapa fase diantaranya: 1) Fase bayi, ialah fase kehidupan manusia terhitung dari saat kelahiran sampai kira-kira berumur dua tahun. Selama rentang waktu itu, kehidupan bayi biasanya sangat tergantung pada bantuan dan pemeliharaan pihak lain, terutama si ibu. Peranan ibu yang demikian besarnya terhadap si bayi itu tentu mempunyai arti tersendiri bagi pendidikannya. 2) fase kanan-kanak. 3) fase anakanak. 4) fase remaja. 5) fase dewasa. Mengucapkan kalimat syahadat bagi orang yang syakar al maut sebagai batas akhir bagi pendidikan orang dewasa. Karena setelah berpisah roh dengan badan, manusia secara fisik sudah berubah menjadi mayat, sedangkan psikis (rohani) nya kembali ke hadhirat Allah.

\section{DAFTAR RUJUKAN}

Alamsyah. (2015). ilmu-ilmu hadits (Ǔlūm alHadisś). CV. Anugrah Utama Raharja (AURA).

Bungin, B. (2011). Komunikasi,Ekonomi,Kebijakan Publik,dan Ilmu Sosial Lainnya. Kencana Prenada Media Group.

Creswell, J. W. (2010). Pendekatan Kualitatif, Kuantitatif dan Mixed (3rd ed.). Pustaka Pelajar.

Darwin. (2018). Pengaruh Penguasaan Ilmu Tajwid dan Tahsin Terhadap hasil belajar Al-quran (Studi Kasus Pada Siswa Madrasah Aliyah Negri 1 Kendari Sulawesi Tenggara). Fikratuna, 9, 82-91.

Ishaq, A. H., \& Nawawi, R. (2017). Ilmu Tajwid Dan Implikasinya Terhadap Ilmu Qira'Ah. Qof, 1(1), 15-24. https://doi.org/10.30762/qof.v1i1.926

Mappanyompa, M. M., \& Mustapa Ali, M. A. M. A. (2017). Urgensi Penggunaan Multimedia Interaktif Terhadap Peningkatan Motivasi Belajar Siswa Dalam Pembelajaran Bahasa Arab Kelas Va Min Malang 2. Ibtida'iy: Jurnal Prodi PGMI, 2(2), 54. https://doi.org/10.31764/ibtidaiy.v2i2.1049

Mubarak, H. (2013). Upaya Guru Al-Qur'an Dalam Mengatasi Kesulitan Belajar Membaca AlQur'an Di Sdit Ukhuwah Banjarmasin. Jurnal Studia Insania, $1(1)$,
https://doi.org/10.18592/jsi.v11.1078

39.

Mulyani, D., Pamungkas, I., \& Inten, D. N. (2018). Al-Quran Literacy for Early Childhood with Storytelling Techniques. Jurnal Obsesi : Jurnal Pendidikan Anak Usia Dini, 2(2), 202. https://doi.org/10.31004/obsesi.v2i2.72

Nazir, M. (2014). Metode Penelitian. Penerbit Ghalia Indonesia.

Prastowo, A. (2011). No image available for this title Metode Penelitian Kualitatif (M. Sandra (ed.)). Ar-Ruzz Media.

Purba, A. (2019). Mendidik Anak dalam Mencintai al- Qur' an ... Mendidik Anak dalam Mencintai al-Qur' an .... 08(02), 347-368.

Rahmi, E. (2019). Buku Modul Metodologi Pengajaran Al-Quran Hadis. Deepublish.

Satria, E., Tresnawati, D., \& Nurvitrya, A. (2015). Pengembangan Aplikasi Pembelajaran Iqra' dan Tajwid Berdasarkan Metode Asy-Syafi'i Menggunakan Sistem Multimedia. Jurnal Algoritma, 12(1), 74-81. https://doi.org/10.33364/algoritma/v.121.74

Shihab, Q. (2011). Membumikan Al-Qur'an (2nd ed.). Penerbit Lentera Hati.

Sugiyono. (2017). Metode Penelitian Kuantitatif Kualitatif dan R\&D. Penerbit Alfabeta.

Sukmadinata, N. S. (2016). Metode penelitian pendidikan (11th ed.).

Usman, A., \& Ansyari, H. (2016). Pelatihan Metode membaca Al- Qur'an Berbasis Qiraah AsySyafi'i bagi Mahasiswa FIK UNM. Prosiding Seminar Nasional, 408-412. 